\title{
The role of chemotherapy and operation on lymphocytes accumulation in peripheral blood obtained from patients with oral squamous cell carcinoma
}

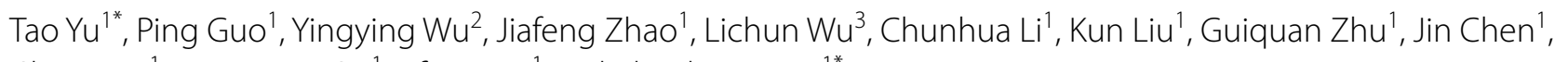
Chuan $\mathrm{Xu}^{1}$, Yongcong Cai ${ }^{1}$, Jifeng $\mathrm{Liu}^{1}$ and Zhaohui Wang ${ }^{1 *}$

*Correspondence: cjyt2006@163.com; zhaohuiwang512@163.com 1 Department of Head and Neck Oncology Surgery, Sichuan Cancer Hospital, No.55, Sec.4, Renminnan Road, Chengdu 610041, Sichuan, People's Republic Ofchina

Full list of author information is available at the end of the article

\begin{abstract}
The "Cancer Immunoediting" concept has provided critical insights suggesting dual functions of immune system during the cancer initiation and development. However, the dynamics and roles of $\mathrm{CD} 4^{+}$and $\mathrm{CD} 8^{+} \mathrm{T}$ cells, $\mathrm{CD} 19^{+} \mathrm{B}$ cells, and $\mathrm{CD} 56^{+} \mathrm{NK}$ cells in the patients with oral squamous cell carcinoma during treatment remain unclear. A total of 43 patients with OSCC were divided into different groups according to different clinical factors (TNM staging, pathological patterns, age and genders) for assessment of relations with $\mathrm{CD}^{+} \mathrm{CD}^{+}{ }^{+}$cells, $\mathrm{CD}^{+} \mathrm{CD}^{+}{ }^{+}$cells, $\mathrm{CD} 3^{-} \mathrm{CD} 19^{+} \mathrm{B}$ cells and $\mathrm{CD} 3^{-} \mathrm{CD} 16^{+} \mathrm{CD} 56^{+} \mathrm{NK}$ cells and different chemotherapy and radical operation. The expression of $\mathrm{CD}^{+} \mathrm{CD}^{+} \mathrm{T}$ cells were significantly increased in advanced tumor stage, large tumor size and positive lymph nodes metastasis, compared to that in early groups. The accumulation of $\mathrm{CD}^{+}{ }^{+} \mathrm{CD} 4^{+} \mathrm{T}$ cells were significantly increased in OSCC patients received 2 cycles $C T$ and radical operation. Moreover, the accumulation of $\mathrm{CD}^{+}{ }^{+} \mathrm{CD} 8^{+} \mathrm{T}$ cells were significantly decreased in OSCC patients received 2 cycles $\mathrm{CT}$ and radical operation. The distribution of circulating $\mathrm{CD}^{-} \mathrm{CD}^{-} 9^{+} \mathrm{B}$ cells was related with radical operation in patients with OSCC. This study indicate that $\mathrm{CD} 4^{+} \mathrm{T}$ cells have opposing roles in OSCC progression and outcomes, which provides new insights relevant for the development of effective cancer immunotherapeutic approaches. 2 cycles TP regime chemotherapy and radical therapy may contribute to increase the effects of anti-tumor immunity on patients with OSCC.
\end{abstract}

Keywords: Oral squamous cell carcinoma, Immune subset, Chemotherapy, Radical operation

\section{Background}

Increasing evidence suggests that interplay between immune cells and tumor cells exerts a major influence on oral tumor development and progression (Sahingur and Yeudall 2015). Furthermore, recent "Cancer Immunoediting" concept provided insights that immune system has both immune surveillance and tumor promotion effects during the cancer development (Dunn et al. 2004; Schreiber et al. 2011). In recent years, with the rapid development of molecular biology and immunology and the multidisciplinary

(c) 2015 Yu et al. This article is distributed under the terms of the Creative Commons Attribution 4.0 International License (http:// creativecommons.org/licenses/by/4.0/), which permits unrestricted use, distribution, and reproduction in any medium, provided you give appropriate credit to the original author(s) and the source, provide a link to the Creative Commons license, and indicate if changes were made. 
cross integration, achievements have been made in the research of mutual regulation among immunological cells in tumor tissues (de Cos Escuin 2014; Liu et al. 2014). Of the examination indexes for diagnosing the development, progression and prognosis of tumors, the detection of lymphocyte subgroups in peripheral blood is the most popular one in clinic (Liu et al. 2014; Jozwik et al. 2015). It is established that an effective anti-tumor immune response requires the involvement of both $\mathrm{CD}^{+}$and $\mathrm{CD} 8^{+} \mathrm{T}$ cells (Dunn et al. 2004; Schreiber et al. 2011). The role of CD4 ${ }^{+} \mathrm{T}$ cells in anti-tumor immunity has recently been extensively studied in both pre-clinical animal models and clinical cancer patients. $\mathrm{CD} 4^{+} \mathrm{T}$ cells are critical for priming of tumor-specific CD8 ${ }^{+}$ $\mathrm{T}$ cells and for the secondary expansion and memory of $\mathrm{CD} 8^{+} \mathrm{T}$ cells as well (Janssen et al. 2003). The immune status of patients is commonly evaluated in terms of circulating lymphocyte subsets, including $\mathrm{CD}^{+} \mathrm{T}$ cells, $\mathrm{CD}^{+} \mathrm{CD}^{+} \mathrm{T}$ cells, $\mathrm{CD}^{+} \mathrm{CD}^{+}$ T cells, CD $19^{+}$B cells and CD56 ${ }^{+}$NK cells (Plonquet et al. 2007; Ersvaer et al. 2007). There are some works on the role of the $\mathrm{T}$ cells in head neck squamous cell carcinoma. Boucek et al. analyzed the blood samples from 112 patients with head and neck squamous cell carcinoma lymphocyte subpopulations $\left(\mathrm{CD}^{+}\right.$; $\mathrm{CD}^{-} \mathrm{CD} 16^{+} \mathrm{CD} 56^{+}$; $\mathrm{CD}^{+}$; $\left.\mathrm{CD}^{+} ; \mathrm{CD}^{+} 9^{+} ; \mathrm{CD}^{+} \mathrm{CD} 45 \mathrm{RA}^{+}\right)$. The results demonstrated that the percentage of $\mathrm{CD} 8^{+}$ cells increased and the $\mathrm{CD} 4 / \mathrm{CD} 8$ ratio decreased with tumor grade. The ratio of $\mathrm{B}$ lymphocytes decreased in patients with locoregional metastases (11.25 versus $9.22 \%)$. Treg $(15.2 \%)$ and $\mathrm{CD}^{+}$cells $(45.3 \%)$ increased, while NK cells $(11.8 \%)$ decreased in HNSCC patients compared to controls (9.0, 38.1 and $15.8 \%$, respectively) (Boucek et al. 2010). Starska et al. performed the cytofluorymetric analysis of the early $\left(\mathrm{CD} 69^{+}, \mathrm{CD} 71^{+}\right)$and late activation markers $\left(\mathrm{CD} 25_{\text {high }}^{+}, \mathrm{CD} 26^{+}, \mathrm{HLA} / \mathrm{DR}^{+}\right)$expression on $\mathrm{T} \mathrm{CD} 3^{+} \mathrm{CD} 4^{+}$and $\mathrm{CD}^{+}{ }^{+} \mathrm{CD} 8^{+}$cells subpopulations in mixed cellular cultures of freshly isolated tumor cells (MLTMC) and non-cancerous normal epithelial cells (MLNCC) in 55 cases of squamous cell laryngeal carcinomal. Meanwhile, the whole peripheral blood concentrations of IL-10 and IFN-g in 21 and $72 \mathrm{~h}$ of experiments were also measured by ELISA. In addition, Starska et al. identified that the expressions of $\mathrm{CD}^{+} 9^{+}$and $\mathrm{CD} 71^{+}$antigens on $\mathrm{T} \mathrm{CD} 3^{+} \mathrm{CD}^{+}$and $\mathrm{CD}^{+}{ }^{+} \mathrm{CD} 8^{+}$cells as well as $\mathrm{CD} 4^{+} \mathrm{HLA} / \mathrm{DR}^{+}$markers were higher for pT3 and pT4 tumors, in comparison with pT2 carcinomas. These studies were similar with our present study (Starska et al. 2011a, b). However, few studies were focused on the dynamic correlation between circulating lymphocyte subsets and different treatments in patients with oral squamous cell carcinoma (OSCC). Furthermore, the influence of chemotherapy (CT) and radical operation on circulating lymphocyte subsets of patients with OSCC remains unclear (Lau et al. 2007; Hsu et al. 2010). In the current study, the correlations between circulating immune subsets and pre- and post-treatment as well as the clinical characteristics were investigated in OSCC patients.

\section{Methods}

Patients

The study protocol was approved by the ethical committee of the Sichuan Cancer Hospital, China and was performed in accordance with the ethical standards laid down in the 1964 Declaration of Helsinki and its later amendments. The clinical data, including age, gender, location, size of tumor, nodal status, histologic type, and treatment were obtained in department of Head and Neck Oncology Surgery, Sichuan Cancer Hospital 
from January 2013 to December 2014. The diagnosis depended on the pathological finding and every case was restaged according to the UICC TNM Classification of Malignant Tumors (The seventh edition). All cases were histologically graded into well, intermediate and poor grade OSCC. The primary locations of tumor were from tongue, buccal, and the floor of mouth. The patients with $\mathrm{T}_{1} / \mathrm{N}_{0}$ OSCC only received radical operation (extensive resection). The patients with $\mathrm{T}_{2-4} / \mathrm{N}_{1-3}$ OSCC received 2 cycles TP regime chemotherapy and then radical operation, including extensive resection of the primary tumor, partial resection of maxillary/mandible, and functional neck dissection (Level I-V). The TP chemotherapy regime was comprised $30 \mathrm{mg} / \mathrm{m}^{2}$ cisplatin on days $1-3$ plus $100 \mathrm{mg} / \mathrm{m}^{2}$ paclitaxel on days 1 .

\section{Immune subset measurement}

Before treatment and 7 days after 2 cycles CT or radical operation, analysis of total lymphocytes and subsets was performed on whole blood samples $\left(100 \mu \mathrm{L} ; 5 \times 10^{5}-1 \times 10^{6}\right.$ cells) collected into EDTA-treated tubes. Blood was stained with the following conjugated murine antihuman monoclonal antibodies (Becton-Dickinson, San Jose, CA, USA): CD4 ( $\mathrm{T}$ helper cells), CD8 (cytotoxic T cells), CD19 (B cells) and CD56 (natural killer cells). The mixtures were incubated for $30 \mathrm{~min}$ in the dark, washed with PBS $(3 \mathrm{~mL})$ and centrifuged at $1500 \mathrm{rpm}$ for $5 \mathrm{~min}$. Cells were analyzed using a multiparametric four-color flow cytometer (BD FACSCalibur, CA, USA). Percentages of circulating $\mathrm{CD}^{+}{ }^{+} \mathrm{CD} 4^{+} \mathrm{T}$ cells, $\mathrm{CD}^{+}{ }^{+} \mathrm{CD} 8^{+} \mathrm{T}$ cells, $\mathrm{CD} 3^{-} \mathrm{CD} 19^{+} \mathrm{B}$ cells and $\mathrm{CD} 3^{-} \mathrm{CD} 16^{+} \mathrm{CD} 56^{+}$ $\mathrm{NK}$ cells were quantified, and $\mathrm{CD} 4^{+} / \mathrm{CD}^{+}$ratios were also calculated with Cellquest software (BD Biosciences).

\section{Statistical analysis}

Data are expressed as mean \pm standard deviation (SD). The significance of difference between groups was determined by paired or unpaired two-tailed Student's $t$ test or the one-way analysis of Variance (ANOVA). Difference was considered significant for $\mathrm{p}$ values less than 0.05 .

\section{Results}

\section{The clinical data}

Patients' age ranged from 23 to 77 years (median 58.8), with 21 cases belonging to the $>60$ age group, accounting for $48.8 \%$ of all patients. The locations of primary tumor were tongue, buccal, and the floor of mouth, respectively. There were 34 male and 9 female subjects. The size of the primary tumor was $1.5-6.0 \mathrm{~cm}$ (median 4.5). According to the seventh edition of the TNM classification, 17 cases were clinically classified as $T_{1-2}$ and 26 cases were clinically classified as $\mathrm{T}_{3-4}$. In addition, 19 cases were clinically classified as $\mathrm{N}_{0}$ and 24 cases were clinically classified as $\mathrm{N}_{1-3}$. Only two cases had lung and bone metastasis. The primary diagnosis was performed by incisional biopsy. 21 were pathologically classified as well differentiated OSCC, 14 cases as intermediate differentiated OSCC, and 8 cases as poor differentiated OSCC. Clinical data of all cases are summarized in Table 1. 
Table 1 Correlations between the percentage of different lymphocyte subgroups and clinicopathologic characteristics in OSCC

\begin{tabular}{|c|c|c|c|c|c|}
\hline Groups & $\mathbf{N}$ & $\mathrm{CD}^{+} \mathrm{CD}^{+}$ & $\mathrm{CD}^{+} \mathrm{CD}^{+}$ & $\mathrm{CD}^{-} \mathrm{CD}^{-} 9^{+}$ & $\mathrm{CD3}^{-} \mathrm{CD}^{-6^{+}}$ \\
\hline \multicolumn{6}{|l|}{ Gender } \\
\hline Male & 34 & $37.27 \pm 8.29$ & $27.79 \pm 5.57$ & $10.24 \pm 5.08$ & $18.75 \pm 9.00$ \\
\hline Female & 9 & $36.56 \pm 7.88$ & $26.44 \pm 4.98$ & $10.58 \pm 3.76$ & $16.49 \pm 8.66$ \\
\hline \multicolumn{6}{|l|}{ Age } \\
\hline$\leq 40$ & 3 & $30.33 \pm 4.04$ & $22.33 \pm 3.51$ & $9.50 \pm 2.17$ & $24.60 \pm 4.85$ \\
\hline $40-60$ & 19 & $39.68 \pm 6.95$ & $29.58 \pm 4.74^{\mathrm{a}}$ & $11.04 \pm 5.63$ & $18.48 \pm 9.42$ \\
\hline$\geq 60$ & 21 & $35.76 \pm 8.84$ & $26.38 \pm 5.55$ & $9.77 \pm 4.29$ & $17.19 \pm 8.73$ \\
\hline \multicolumn{6}{|l|}{ Location } \\
\hline Tongue & 21 & $38.1 \pm 8.09$ & $27.33 \pm 5.17$ & $11.03 \pm 5.89$ & $19.14 \pm 8.97$ \\
\hline Floor of mouth & 13 & $36.69 \pm 8.04$ & $27.92 \pm 5.82$ & $9.60 \pm 3.35$ & $17.06 \pm 9.00$ \\
\hline Buccal & 9 & $35.44 \pm 8.93$ & $27.33 \pm 6.02$ & $9.66 \pm 3.85$ & $18.02 \pm 9.31$ \\
\hline \multicolumn{6}{|l|}{ Tumor size } \\
\hline $\mathrm{T}_{1-2}$ & 17 & $29.06 \pm 3.44^{b}$ & $22.65 \pm 3.10^{c}$ & $1048 \pm 4.52$ & $15.82 \pm 8.39$ \\
\hline $\mathrm{T}_{3-4}$ & 26 & $42.39 \pm 5.49$ & $30.69 \pm 4.08$ & $10.20 \pm 5.06$ & $19.89 \pm 8.98$ \\
\hline \multicolumn{6}{|l|}{ Nodal status } \\
\hline $\mathrm{N}_{0}$ & 19 & $30.58 \pm 5.04^{d}$ & $24 \pm 4.66^{\mathrm{e}}$ & $1045 \pm 4.78$ & $17.48 \pm 9.34$ \\
\hline $\mathrm{N}_{1-3}$ & 24 & $42.29 \pm 6.10$ & $30.29 \pm 4.30$ & $10.20 \pm 4.91$ & $18.91 \pm 8.65$ \\
\hline \multicolumn{6}{|l|}{ Pathological grading } \\
\hline Well differentiated & 21 & $40.75 \pm 7.05$ & $29.52 \pm 5.12$ & $10.48 \pm 5.58$ & $18.55 \pm 8.19$ \\
\hline Intermediate differentiated & 14 & $33.14 \pm 6.37$ & $25 \pm 4.99$ & $10.03 \pm 4.31$ & $19.26 \pm 10.39$ \\
\hline Poor differentiated & 8 & $33.75 \pm 8.46$ & $26.63 \pm 5.42$ & $10.36 \pm 3.79$ & $15.85 \pm 8.47$ \\
\hline \multicolumn{6}{|c|}{ a Compared with $\leq 40$ group and $\geq 60$ group, $a<0.05$} \\
\hline \multicolumn{6}{|c|}{ b Compared with $\mathrm{T}_{3-4}$ group, $b<0.0001$} \\
\hline \multicolumn{6}{|c|}{ c Compared with $\mathrm{T}_{3-4}$ group, $b<0.0001$} \\
\hline \multicolumn{6}{|c|}{${ }^{\mathrm{d}}$ Compared with $\mathrm{N}_{1-3}$ group, $b<0.0001$} \\
\hline e Compared with $\mathrm{N}_{1-3}$ group, $b<$ & & & & & \\
\hline
\end{tabular}

\section{Accumulation of $\mathrm{CD}_{3}{ }^{+} \mathrm{CD}^{+}{ }^{+}, \mathrm{CD}^{+}{ }^{+} \mathrm{CD} 8^{+} \mathrm{T}$ cells, $\mathrm{CD}^{-}{ }^{-} \mathrm{CD} 19^{+} \mathrm{B}$ cells, and $\mathrm{CD} 3^{-} \mathrm{CD} 56^{+} \mathrm{NK}$} cells subsets in different OSCC development and progression

To better understand the interactions and role of immune system in the pathogenesis of OSCC, four lymphocyte subtypes $\left(\mathrm{CD}^{+} \mathrm{CD}^{+}, \mathrm{CD}^{+} \mathrm{CD}^{+} \mathrm{T}\right.$ cells, $\mathrm{CD} 3^{-} \mathrm{CD} 19^{+}$ $\mathrm{B}$ cells, and $\mathrm{CD} 3^{-} \mathrm{CD} 16^{+} \mathrm{CD} 56^{+} \mathrm{NK}$ cells) were analyzed from peripheral blood using flow cytometer. Firstly, we analyzed the role of different clinical data on four lymphocyte subtypes in OSCC. The results demonstrated that there were no differences of lymphocyte subtypes change between female and male and among different location. There was only significant difference of $\mathrm{CD}^{+} \mathrm{CD}^{+} \mathrm{T}$ cells numbers in 40-60 age group, compared to $\leq 40$ age group and $\geq 60$ age group $(\mathrm{P}<0.05)$ (Fig. 1). Notably, the percentage of $\mathrm{CD}^{+} \mathrm{CD}^{+} \mathrm{T}$ cells and $\mathrm{CD} 3^{+} \mathrm{CD} 8^{+} \mathrm{T}$ cells distribution was significantly different in OSCC patients with different tumor size and nodal status. The percentage of $\mathrm{CD} 3{ }^{+} \mathrm{CD} 4{ }^{+}$ $\mathrm{T}$ cells distribution was significantly increased in OSCC patients with $\mathrm{T}_{3-4}$ tumor size $(42.39 \pm 5.49)$, compared to that with $\mathrm{T}_{1-2}$ tumor size $(29.06 \pm 3.44)$. The percentage of $\mathrm{CD}^{+} \mathrm{CD}^{+} \mathrm{T}$ cells distribution was significantly increased in OSCC patients with $\mathrm{T}_{3-4}$ tumor size $(30.69 \pm 4.08)$, compared to that with $\mathrm{T}_{1-2}$ tumor size $(22.65 \pm 3.10)$. The same tendency was also observed in patients with different nodal status. The percentage of $\mathrm{CD}^{+} \mathrm{CD}^{+} \mathrm{T}$ cells distribution was significantly increased in OSCC patients 

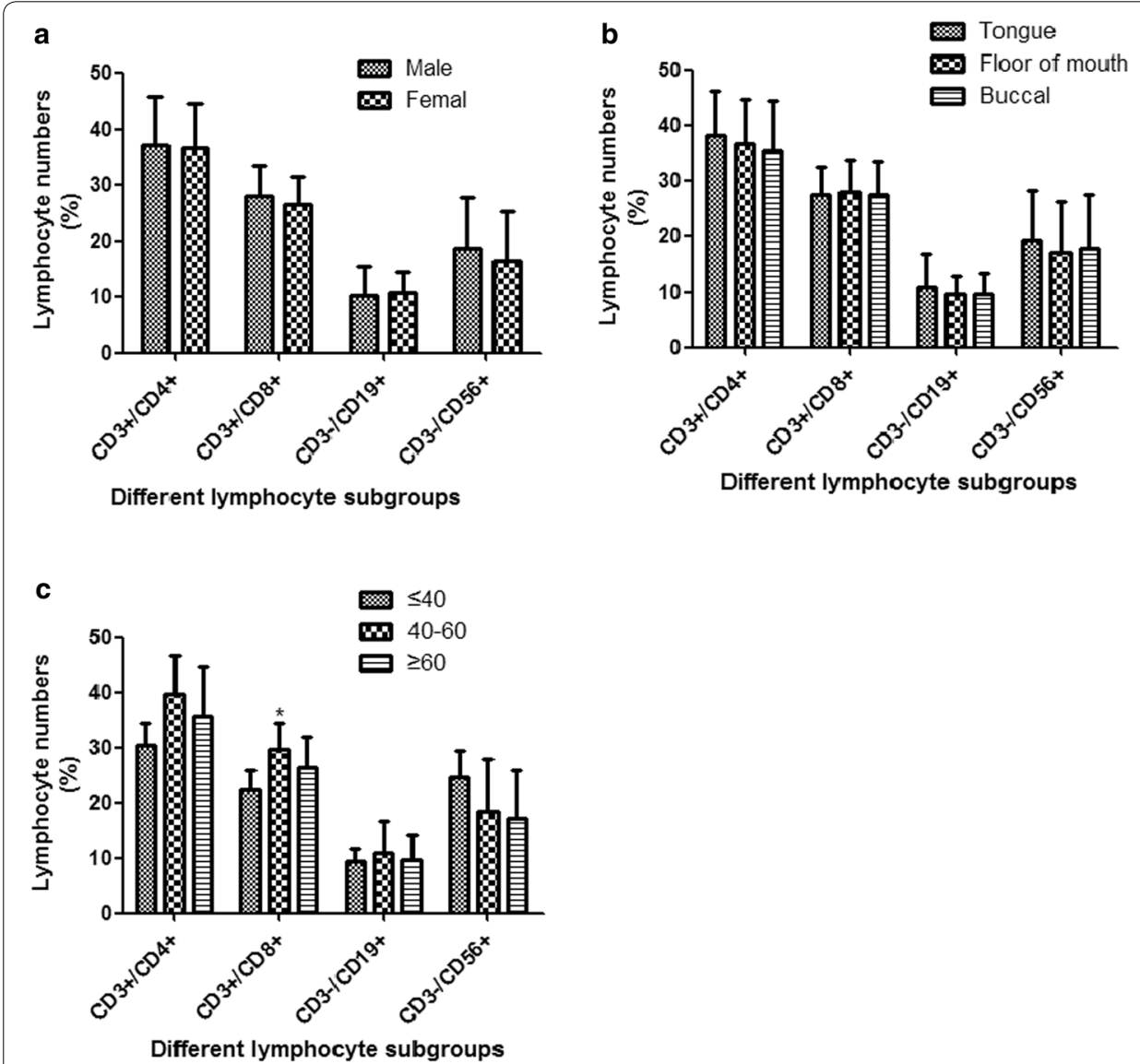

Fig. 1 Accumulation of lymphocyte subgroups in OSCC patients with different clinical characteristics. a The percentage of circulating $\mathrm{CD}^{+}{ }^{+} \mathrm{CD} 4^{+}$and $\mathrm{CD} 3^{+} \mathrm{CD} 8^{+} \mathrm{T}$ cells, $\mathrm{CD} 3^{-} \mathrm{CD} 19^{+} \mathrm{B}$ cells, and $\mathrm{CD} 3^{-} \mathrm{CD} 16^{+} \mathrm{CD} 56^{+} \mathrm{NK}$ cells in the OSCC patients with different gender; $\mathbf{b}$ the percentage of circulating $\mathrm{CD}^{+}{ }^{+} \mathrm{CD} 4^{+}$and $\mathrm{CD} 3^{+} \mathrm{CD}^{+}$ T cells, $\mathrm{CD}^{-} \mathrm{CD} 19^{+} \mathrm{B}$ cells, and $\mathrm{CD} 3^{-} \mathrm{CD} 16^{+} \mathrm{CD} 56^{+} \mathrm{NK}$ cells in the OSCC patients with different location of primary tumor; $\mathbf{c}$ the percentage of circulating $\mathrm{CD}^{+}{ }^{+} \mathrm{CD} 4^{+}$and $\mathrm{CD} 3^{+} \mathrm{CD} 8^{+} \mathrm{T}$ cells, $\mathrm{CD} 3^{-} \mathrm{CD} 19^{+} \mathrm{B}$ cells, and $\mathrm{CD}^{-} \mathrm{CD}_{16}{ }^{+} \mathrm{CD} 56^{+} \mathrm{NK}$ cells in the OSCC patients with different age. Error bars indicate mean $\pm \mathrm{SD},{ }^{*} \mathrm{P}<0.05$

with $\mathrm{N}_{1-3}(42.29 \pm 6.10)$, compared to that with $\mathrm{N}_{0}(30.58 \pm 5.04)$. The percentage of $\mathrm{CD}^{+} \mathrm{CD}^{+} \mathrm{T}$ cells distribution was also significantly increased in OSCC patients with $\mathrm{N}_{1-3}(30.29 \pm 4.30)$, compared to that with $\mathrm{N}_{0}(24 \pm 4.66)$.

\section{Dynamic distributions of $\mathrm{CD} 4^{+}, \mathrm{CD} 8^{+} \mathrm{T}$ cells, $\mathrm{CD} 19^{+} \mathrm{B}$ cells, and $\mathrm{CD} 56^{+} \mathrm{NK}$ cells subsets in patients with different tumor size of OSCC received different treatments}

To investigate the dynamic distributions of four lymphocyte subtypes in OSCC with different TNM classification received two-cycle chemotherapy and radical operation, we analyzed the percentage of $\mathrm{CD}^{+} \mathrm{CD}^{+}, \mathrm{CD}^{+}{ }^{+} \mathrm{CD} 8^{+} \mathrm{T}$ cells, $\mathrm{CD} 3^{-} \mathrm{CD} 19^{+} \mathrm{B}$ cells, and $\mathrm{CD} 3^{-} \mathrm{CD} 16^{+} \mathrm{CD} 56^{+} \mathrm{NK}$ cells distribution in different time point, including 3 days before treatment, 1 week after 1 cycle chemotherapy, 1 week after 2 cycles chemotherapy, and 1 week after radical operation. According to UICC TNM classification, we analyzed the four lymphocyte subtypes distribution in patients with tumor size $\left(\mathrm{T}_{1-2}\right)$ in four time points, compared to patients with tumor size $\left(\mathrm{T}_{3-4}\right)$. The result demonstrated that there was no difference of $\mathrm{CD} 3{ }^{+} \mathrm{CD} 4{ }^{+} \mathrm{T}$ cells distribution in patients with $\mathrm{T}_{1-2}$ tumors 
(see figure on next page.)

Fig. 2 The accumulation of lymphocyte subgroups in OSCC patients with different tumor size received different treatments. $\mathbf{a}$ The accumulation of $\mathrm{CD}_{3}{ }^{+} \mathrm{CD}^{+} \mathrm{T}$ cells in the OSCC patients with $\mathrm{T}_{1-2}$ size of primary tumor received different treatments; $\mathbf{b}$ the accumulation of $\mathrm{CD}_{3}{ }^{+} \mathrm{CD} 8^{+} \mathrm{T}$ cells in the OSCC patients with $\mathrm{T}_{1-2}$ size of primary tumor received different treatments; $\mathbf{c}$ the accumulation of $\mathrm{CD}^{-} \mathrm{CD} 19^{+} \mathrm{B}$ cells in the OSCC patients with $\mathrm{T}_{1-2}$ size of primary tumor received different treatments; $\mathbf{d}$ the accumulation of $\mathrm{CD}^{-} \mathrm{CD}_{16}{ }^{+} \mathrm{CD} 56^{+} \mathrm{NK}$ cells in the OSCC patients with $\mathrm{T}_{1-2}$ size of primary tumor received different treatments; $\mathbf{e}$ the accumulation of $\mathrm{CD}_{3}{ }^{+} \mathrm{CD}^{+} \mathrm{T}$ cells in the OSCC patients with $\mathrm{T}_{1-2}$ size of primary tumor received different treatments; $\mathbf{f}$ the accumulation of $\mathrm{CD}^{+}{ }^{+} \mathrm{CD} 8^{+} \mathrm{T}$ cells in the OSCC patients with $\mathrm{T}_{3-4}$ size of primary tumor received different treatments; $\mathbf{g}$ the accumulation of $\mathrm{CD}_{3}^{-} \mathrm{CD} 19^{+} \mathrm{T}$ cells in the OSCC patients with $\mathrm{T}_{3-4}$ size of primary tumor received different treatments; $\mathbf{h}$ the accumulation of $\mathrm{CD}_{3}^{-} \mathrm{CD}_{16}{ }^{+} \mathrm{CD}_{5} 6^{+} \mathrm{NK}$ cells in the OSCC patients with $T_{3-4}$ size of primary tumor received different treatments. Error bars indicate mean $\pm S D$, ${ }^{*} P<0.05$, ${ }^{* *} P<0.0001$

with no treatment in comparison with the 1 week after 1 cycle chemotherapy. But for patients with $\mathrm{T}_{1-2}$ tumors received 2 cycles $\mathrm{CT}$ and radical operation, the percentage of $\mathrm{CD}^{+} \mathrm{CD} 4^{+} \mathrm{T}$ cells distribution was significantly increased, compared to that with no treatment and 1 week after 1 cycle CT $(\mathrm{P}<0.0001)$ (Fig. 2a). Moreover, there was no difference in patients with no treatment and 1 week after 1 cycle CT, and between 1 week after 2 cycles $\mathrm{CT}$ and post-operation. For $\mathrm{CD}^{+} \mathrm{CD}^{+} \mathrm{T}$ cells distribution, we observed that the $\mathrm{T}$ cells distribution was significantly decreased in patients with $\mathrm{T}_{1-2}$ received 2 cycles $\mathrm{CT}$ or radical operation, compared to the patients with $\mathrm{T}_{1-2}$ received no treatment or 1 cycle $\mathrm{CT}(\mathrm{P}<0.0001)$. Interestingly, $\mathrm{CD}^{+} \mathrm{CD}^{+} \mathrm{T}$ cells seems to be increased in patients with $\mathrm{T}_{1-2}$ received 1 cycle $\mathrm{CT}$, compared to that received no treatment (Fig. 2b). We also analyzed the $\mathrm{CD} 3^{-} \mathrm{CD} 19^{+} \mathrm{B}$ cells and $\mathrm{CD} 3^{-} \mathrm{CD} 16^{+} \mathrm{CD} 56^{+} \mathrm{NK}$ cells distribution in different time points for these patients. The $\mathrm{CD}^{-} \mathrm{CD} 19^{+} \mathrm{B}$ cells distribution only increased in patients with $\mathrm{T}_{1-2}$ received radical operation, compared to the time point of no treatment or $1-2$ cycles $C T$ ( $p<0.0001$ ) (Fig. 2c). There seems to be no difference for $\mathrm{CD}^{-} \mathrm{CD} 16^{+} \mathrm{CD} 56^{+} \mathrm{NK}$ cells distribution in all four time points (Fig. 2d). Almost the same tendency was observed in OSCC patients with $\mathrm{T}_{3-4}$ tumor size. For patients with $\mathrm{T}_{3-4}$ tumors received 2 cycles $\mathrm{CT}$ and radical operation, the percentage of $\mathrm{CD}^{+} \mathrm{CD} 4^{+} \mathrm{T}$ cells distribution was significantly increased, compared to the time points of no treatment and 1 cycle CT $(\mathrm{P}<0.0001)$ (Fig. 2e). Two-cycles CT and radical operation significantly decreased the percentage of $\mathrm{CD}^{+} \mathrm{CD}^{+} \mathrm{T}$ cells, compared to the time points of no treatment or 1 cycle CT ( $p<0.0001$ ) (Fig. 2f). The radical operation is the only time point to increase the distribution of $\mathrm{CD}^{-} \mathrm{CD} 19^{+} \mathrm{B}$ cells in comparison with the other three time points $(\mathrm{p}<0.05)$ (Fig. 2g). The distribution of $\mathrm{CD}^{-} \mathrm{CD} 16^{+} \mathrm{CD} 56^{+}$ NK cells was still no change in all four time points (Fig. $2 \mathrm{~h}$ ).

\section{Dynamic distributions of $\mathrm{CD}^{+}{ }^{+}, \mathrm{CD}^{+} \mathrm{T}$ cells, $\mathrm{CD} 19^{+} \mathrm{B}$ cells, and $\mathrm{CD} 56^{+} \mathrm{NK}$ cells subsets in patients with different nodal status of OSCC received different treatments}

To evaluate the role of nodal status on lymphocyte subtypes distribution in OSCC patients received different treatments, we also analyzed the percentage of $\mathrm{CD} 4^{+}, \mathrm{CD} 8^{+}$ T cells, $\mathrm{CD} 19^{+} \mathrm{B}$ cells, and CD56 ${ }^{+} \mathrm{NK}$ cells distribution using flow cytometer. Similarly, the percentage of $\mathrm{CD}^{+} \mathrm{CD}^{+} \mathrm{T}$ cells distribution was significantly increased in OSCC patients received 2 cycles $\mathrm{CT}$ and radical operation, compared to that received no treatment and 1 cycle CT $(\mathrm{P}<0.0001)$ (Fig. 3a). There were also no differences between the patients received no treatment and 1 cycle $\mathrm{CT}$, and between the patients received 2 cycles $\mathrm{CT}$ and radical operation. The percentage of $\mathrm{CD}^{+} \mathrm{CD}^{+} \mathrm{T}$ cells distribution 


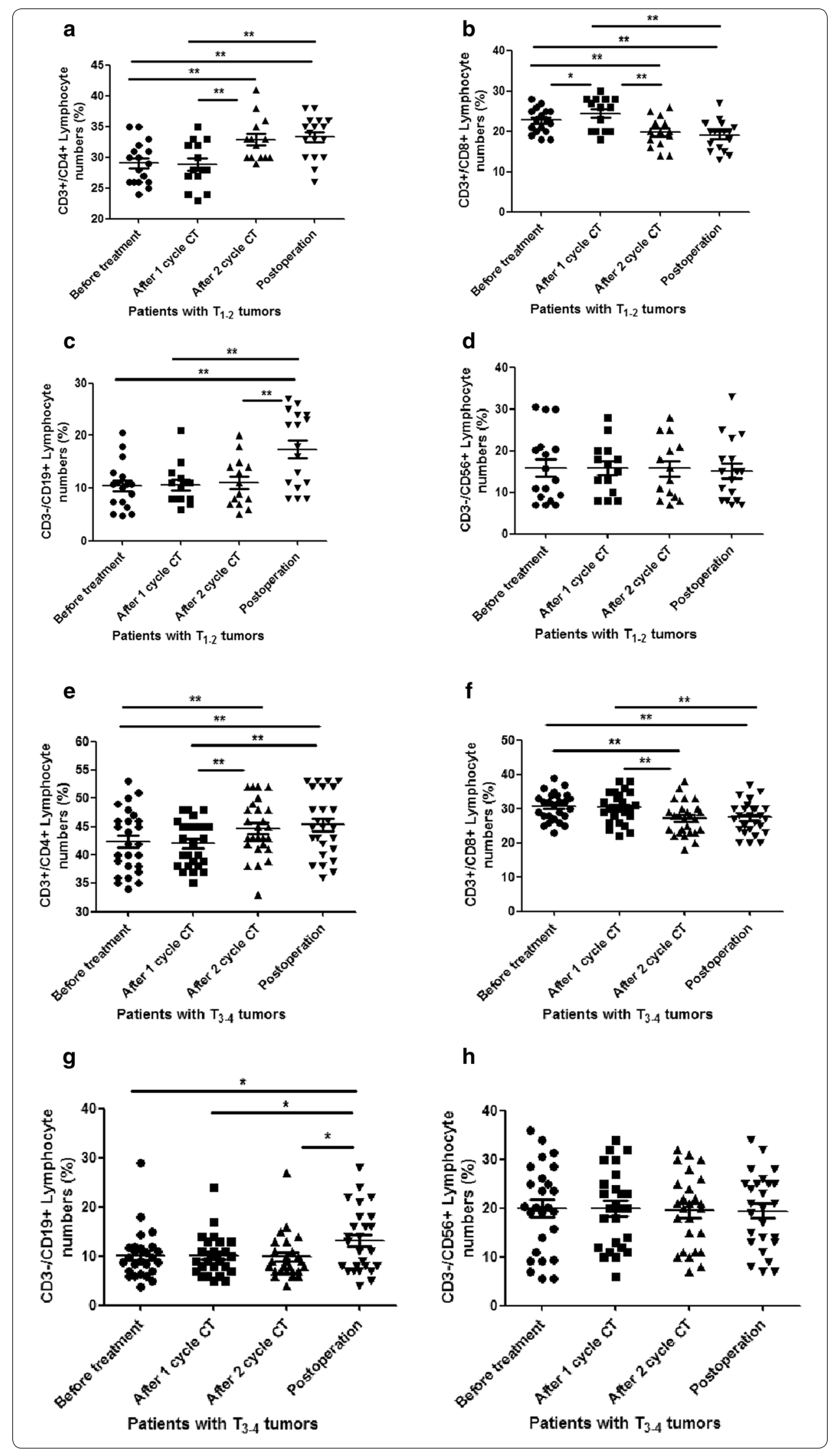


(see figure on next page.)

Fig. 3 The accumulation of lymphocyte subgroups in OSCC patients with different nodal status received different treatments. a The accumulation of $\mathrm{CD}_{3}{ }^{+} \mathrm{CD} 4^{+} \mathrm{T}$ cells in the OSCC patients with $\mathrm{N}_{0}$ received different treatments; $\mathbf{b}$ the accumulation of $\mathrm{CD}_{3}{ }^{+} \mathrm{CD} 8^{+} \mathrm{T}$ cells in the OSCC patients with $\mathrm{N}_{0}$ received different treatments; $\mathbf{c}$ the accumulation of $\mathrm{CD}^{-} \mathrm{CD}_{1} 9^{+} \mathrm{B}$ cells in the OSCC patients with $\mathrm{N}_{0}$ received different treatments; d the accumulation of $\mathrm{CD}^{-}{ }^{-} \mathrm{CD} 16^{+} \mathrm{CD}_{5} 6^{+} \mathrm{NK}$ cells in the OSCC patients with $\mathrm{N}_{0}$ received different treatments; $\mathbf{e}$ the accumulation of $\mathrm{CD}_{3}{ }^{+} \mathrm{CD} 4^{+} \mathrm{T}$ cells in the OSCC patients with $\mathrm{N}_{1-3}$ received different treatments; $\mathbf{f}$ the accumulation of $\mathrm{CD}^{+} \mathrm{CD}^{+} \mathrm{T}$ cells in the OSCC patients with $\mathrm{N}_{1-3}$ received different treatments; $\mathbf{g}$ the accumulation of $\mathrm{CD}^{-}{ }^{-} \mathrm{CD} 19^{+} T$ cells in the OSCC patients with $\mathrm{N}_{1-3}$ received different treatments; $\mathbf{h}$ the accumulation of $\mathrm{CD}^{-} \mathrm{CD}_{16} 6^{+} \mathrm{CD} 56^{+} \mathrm{NK}$ cells in the OSCC patients with $\mathrm{N}_{1-3}$ received different treatments. Error bars indicate mean $\pm \mathrm{SD},{ }^{*} \mathrm{P}<0.05$, ${ }^{* *} \mathrm{P}<0.0001$

significantly decreased in OSCC patients with no lymph nodes metastasis received 2 cycles CT and radical operation, compared to that received no treatment and 1 cycle CT (Fig. 3b). The OSCC patients with no lymph nodes metastasis demonstrated that the $\mathrm{CD}^{-} \mathrm{CD} 19^{+} \mathrm{B}$ cells distribution significantly increased in time point of post-operation, compared to the other three time points $(\mathrm{p}<0.0001)$ (Fig. 3c). There was also no difference distribution of $\mathrm{CD} 3{ }^{-} \mathrm{CD} 16^{+} \mathrm{CD} 56^{+} \mathrm{NK}$ cells among four time points in OSCC patients with no lymph nodes metastasis (Fig. 3d). We also analyzed the percentage of four lymphocyte subtypes distribution in OSCC patients with $\mathrm{N}_{1-3}$ lymph nodes metastasis received different treatments. The results demonstrated that the $\mathrm{CD} 3^{+} \mathrm{CD} 4^{+}$ $\mathrm{T}$ cells distribution was significantly increased in patients with $\mathrm{N}_{1-3}$ received 2 cycles $\mathrm{CT}$ and radical operation, compared to that received no treatment and 1 cycle CT $(\mathrm{p}<0.0001)$ (Fig. 3e). Interestingly, after 1 cycle $\mathrm{CT}$, the $\mathrm{CD}^{+} \mathrm{CD}^{+} \mathrm{T}$ cells distribution was significantly decreased in the patients with $\mathrm{N}_{2-3}$, compared to that received no treatment. The percentage of $\mathrm{CD}^{+} \mathrm{CD}^{+} \mathrm{T}$ cells distribution significantly decreased in patients with $\mathrm{N}_{1-3}$ received 2 cycles $\mathrm{CT}$ and radical operation (Fig. 3f). We also analyzed the $\mathrm{CD}^{-} \mathrm{CD} 19^{+} \mathrm{B}$ cells and $\mathrm{CD} 3^{-} \mathrm{CD} 16^{+} \mathrm{CD} 56^{+} \mathrm{NK}$ cells distribution in different time points for these patients. The $\mathrm{CD} 3^{-} \mathrm{CD} 19^{+} \mathrm{B}$ cells distribution significantly increased in patients with $\mathrm{N}_{1-3}$ received radical operation, compared to that received 2 cycles $\mathrm{CT}$ $(\mathrm{P}<0.05), 1$ cycle CT ( $\mathrm{p}<0.0001)$, and no treatment $(\mathrm{p}<0.0001)$ (Fig. 3g). There was no difference for $\mathrm{CD}^{-} \mathrm{CD}^{-} 6^{+} \mathrm{CD} 56^{+} \mathrm{NK}$ cells distribution in patients with $\mathrm{N}_{1-3}$ in all four time points (Fig. 3h).

\section{Dynamic distributions of $\mathrm{CD} 4^{+}, \mathrm{CD} 8^{+} \mathrm{T}$ cells, $\mathrm{CD} 19^{+} \mathrm{B}$ cells, and $\mathrm{CD} 56^{+} \mathrm{NK}$ cells subsets in patients with different pathologic grading of OSCC received different treatments}

Then we analyzed the percentage of $\mathrm{CD} 4^{+}, \mathrm{CD}^{+} \mathrm{T}$ cells, $\mathrm{CD} 19^{+} \mathrm{B}$ cells, and $\mathrm{CD} 56^{+}$ NK cells distribution using flow cytometer in OSCC patients with different pathological grading. For patients with well differentiated tumors, the percentage of $\mathrm{CD} 3{ }^{+} \mathrm{CD} 4{ }^{+} \mathrm{T}$ cells distribution was significantly increased for patients received 2 cycles $\mathrm{CT}$ and radical operation, compared to the that received no treatment and 1 cycle CT $(\mathrm{P}<0.0001$, $\mathrm{p}<0.05$, respectively) (Fig. 4a). Two-cycle $\mathrm{CT}$ and radical operation significantly decreased the percentage of $\mathrm{CD}^{+} \mathrm{CD}^{+} \mathrm{T}$ cells, compared to the time points of no treatment or 1 cycle CT $(\mathrm{p}<0.0001)$ (Fig. $4 \mathrm{~b})$. The radical operation is the only time point to increase the distribution of $\mathrm{CD} 3^{-} \mathrm{CD} 19^{+} \mathrm{B}$ cells in comparison with the other three time points $(\mathrm{p}<0.0001)$ (Fig. 4c). The distribution of $\mathrm{CD} 3^{-} \mathrm{CD} 16^{+} \mathrm{CD}^{2} 6^{+} \mathrm{NK}$ cells was still no change in all four time points (Fig. $4 \mathrm{~d}$ ). The same tendency was observed in $\mathrm{CD}^{+} \mathrm{CD} 4^{+}$ 


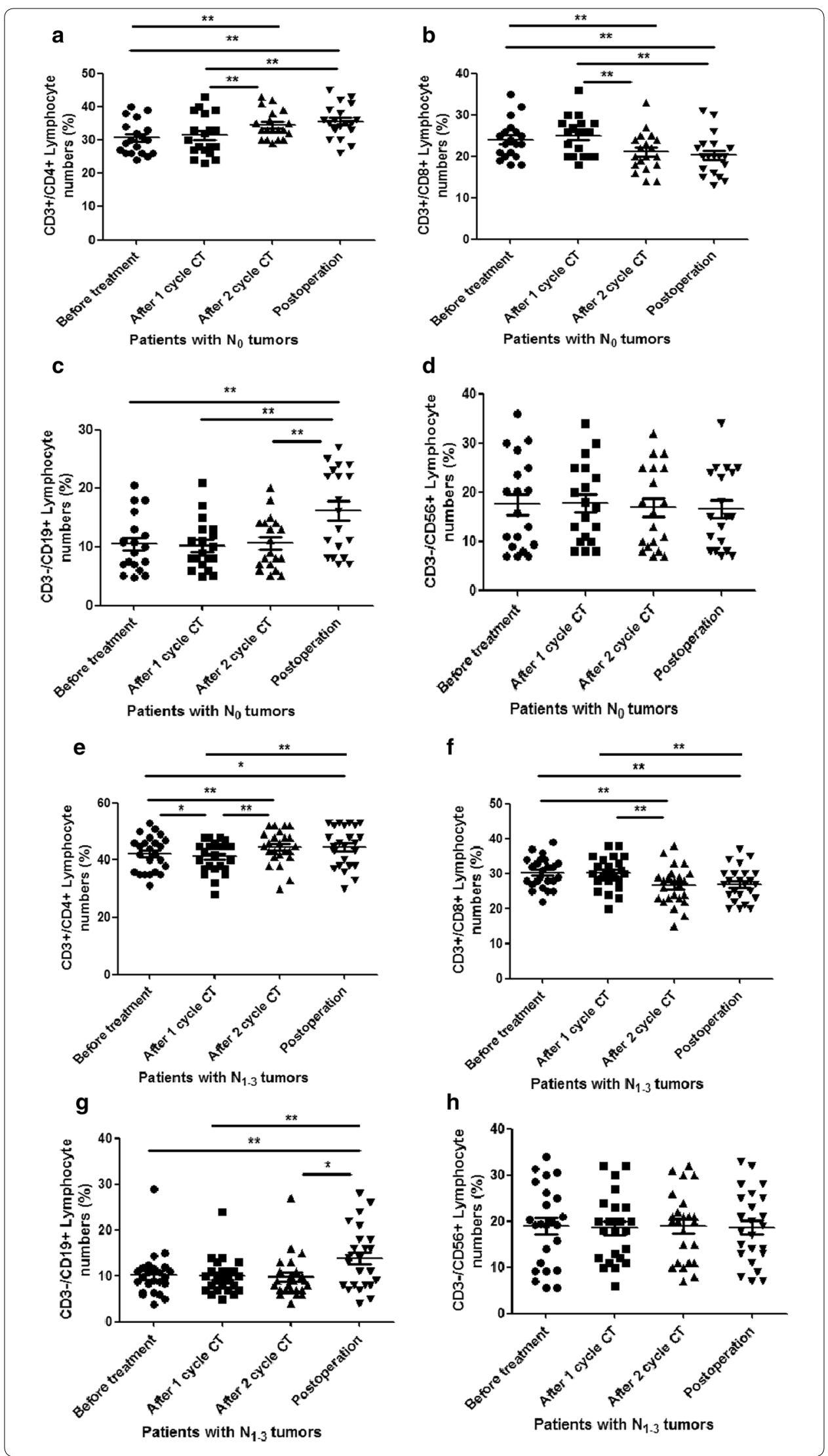


$\mathrm{T}$ cells distribution in these patients received different treatments as those patients with intermediate differentiated tumors (Fig. 4e). Moreover, two-cycle CT and radical operation significantly decreased the percentage of $\mathrm{CD} 3^{+} \mathrm{CD} 8^{+} \mathrm{T}$ cells, compared to the time points of no treatment or 1 cycle CT ( $<0.0001)$. However, 1 cycle CT seems to be increased the percentage of $\mathrm{CD}^{+} \mathrm{CD}^{+} \mathrm{T}$ cells, compared to the patients received no treatment (Fig. 4f). There was significant difference of $\mathrm{CD} 3^{-} \mathrm{CD} 19^{+} \mathrm{B}$ cells between patients with intermediate differentiated tumors received radical operation and that received no treatment, and between patients with intermediate differentiated tumors received radical operation and that received 1 cycle CT (Fig. 4g). The distribution of $\mathrm{CD}^{-}{ }^{-} \mathrm{CD} 16^{+} \mathrm{CD}^{2} 6^{+} \mathrm{NK}$ cells was still no change in all four time points (Fig. 4h). At last, we analyzed that the $\mathrm{CD} 4^{+}, \mathrm{CD}^{+} \mathrm{T}$ cells, $\mathrm{CD} 19^{+} \mathrm{B}$ cells, and $\mathrm{CD} 56^{+} \mathrm{NK}$ cells distribution using flow cytometer in OSCC patients with poor differentiated tumors received different treatments. The percentage of $\mathrm{CD}^{+} \mathrm{CD}^{+} \mathrm{T}$ cells distribution was significantly increased in patients received 1cycle CT, 2 cycles CT and radical operation, compared to the time points of no treatment $(\mathrm{P}<0.0001)$ (Fig. 4i). The percentage of $\mathrm{CD}^{+} \mathrm{CD}^{+}$ $\mathrm{T}$ cells distribution was also significantly decreased in patients with poor differentiated tumors received 1 cycle CT ( $<<0.0001), 2$ cycles CT ( $<<0.05)$, and radical operation $(\mathrm{p}<0.0001)$, compared to that patients received no treatment. Moreover, the radical operation significantly increased the distribution of $\mathrm{CD}^{-} \mathrm{CD} 19^{+} \mathrm{B}$ cells in patients with poor differentiated tumors, compared to that received no treatment and 1 cycle CT (Fig. 4j). However, 2 cycles CT seems to be decreased the distribution of $\mathrm{CD}^{-} \mathrm{CD}^{-} 9^{+} \mathrm{B}$ cells in patients with poor differentiated tumors, compared to that received 1 cycle CT and radical operation (Fig. 4k). The distribution of $\mathrm{CD} 3^{-} \mathrm{CD} 16^{+} \mathrm{CD} 56^{+} \mathrm{NK}$ cells was still no change in all four time points (Fig. 4l).

\section{Association of $\mathrm{CD}^{+} / \mathrm{CD8}^{+}$ratio with OSCC patients received different treatments}

To evaluate the effect of different treatments on patients with OSCC, we also analyze the $\mathrm{CD}^{+} / \mathrm{CD}^{+}$ratio in all OSCC patients received no treatment, 1 cycle CT, 2 cycles $\mathrm{CT}$, and radical operation. The 2 cycles $\mathrm{CT}$ and radical operation indeed increased the $\mathrm{CD} 4^{+} / \mathrm{CD}^{+}$ratio in OSCC patients, compared to that received no treatment or 1 cycle CT $(\mathrm{P}<0.0001)$. There was no significant difference between patients received no treatment and patients received 1 cycle CT, between patients received 2 cycles $\mathrm{CT}$ and patients received radical operation (Fig. 5). These data suggested that the 2 cycles CT and radical operation treatment may be essential to increase the effect of treatment for the patients with OSCC.

\section{Discussion}

Kuhn et al. reported that abnormal $\mathrm{T}$ lymphocyte subgroups were found in peripheral blood, marked by decreased $\mathrm{CD}^{+} \mathrm{CD}^{+}$expression and increased $\mathrm{CD} 3^{+} \mathrm{CD} 8^{+}$expression (Kuhn et al. 2013). However, comprehensive understanding of the role of CD4 ${ }^{+}$ $\mathrm{T}$ cells in anti-tumor immunity is challenging in tumor immunology research and the results have been controversial. Besides the traditional functions of Th1 and Th2 cells in helping tumor-specific CD8 ${ }^{+} \mathrm{T}$ cells and B cells, recent discovery of Th17 and Treg cells has not only resulted in an explosion of cancer immunological research but also markedly changed our conventional thinking of the role of $\mathrm{CD} 4^{+} \mathrm{T}$ cells in the pathologenesis 


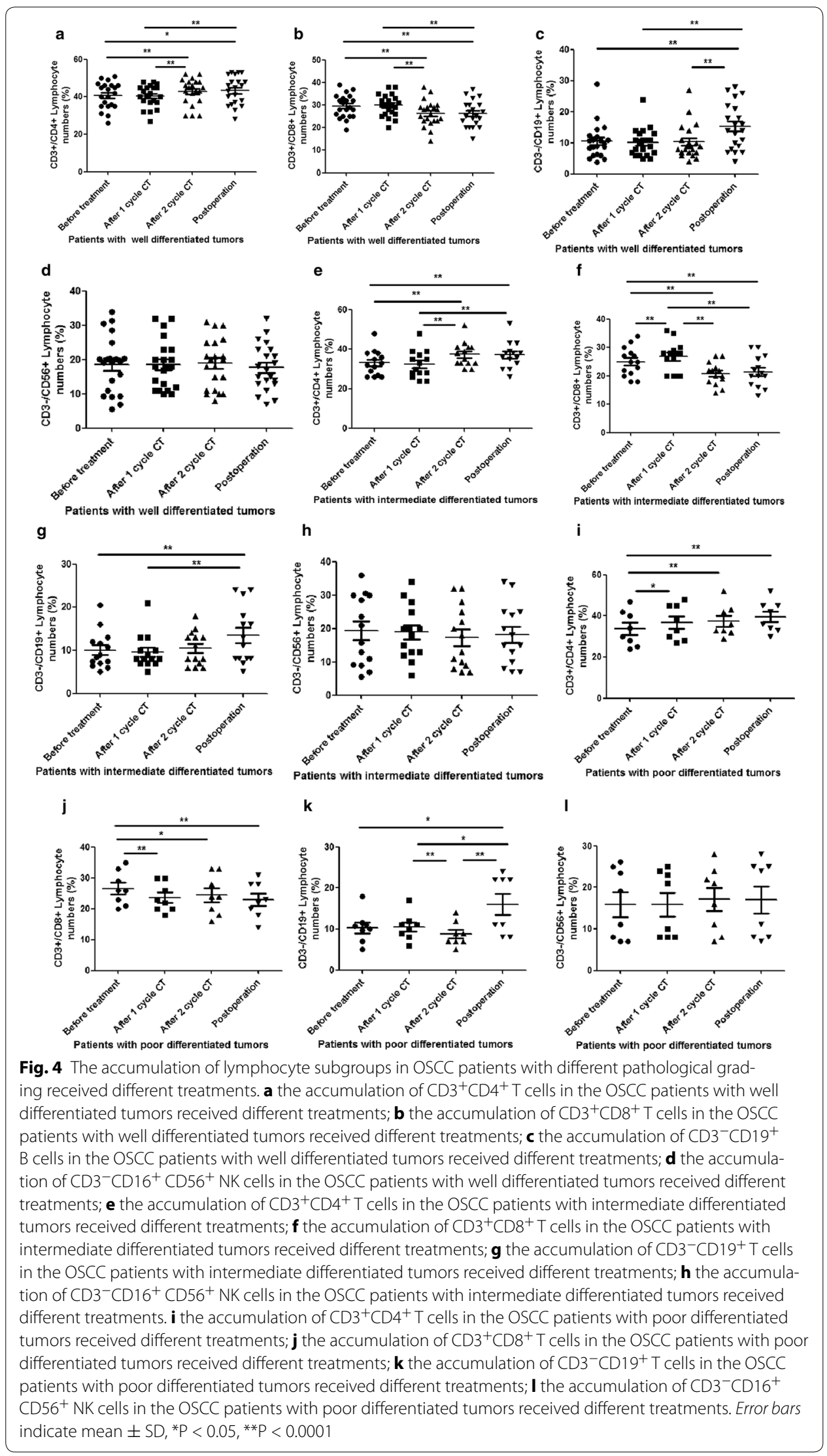




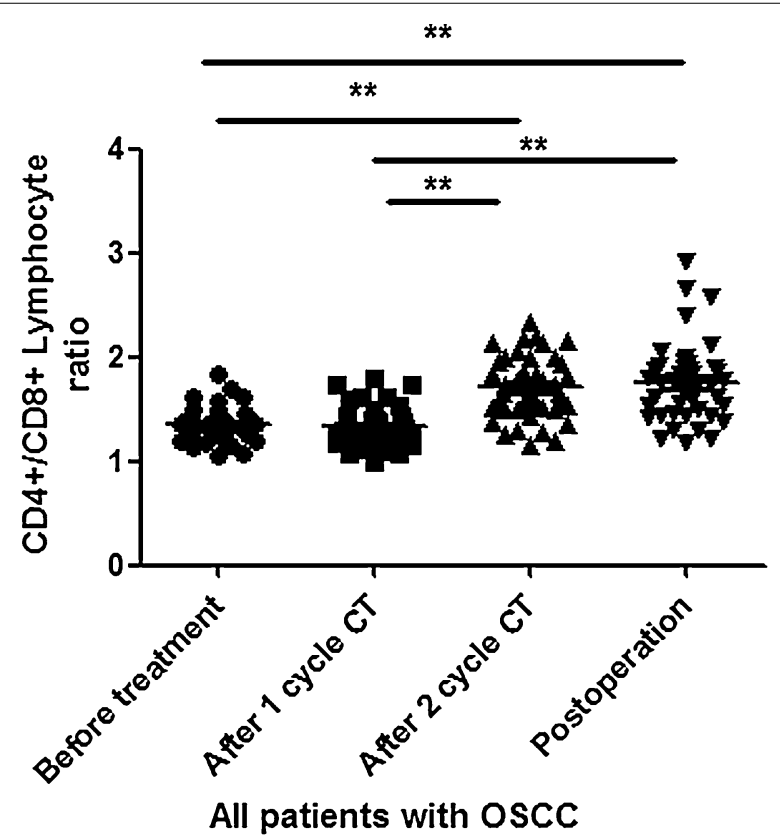

Fig. 5 The $C D 4^{+} / C D 8^{+}$ratio in OSCC patients received different treatments. Error bars indicate mean $\pm S D$, ${ }^{* *} \mathrm{P}<0.0001$

of cancer development. In this study, OSCC patients in advanced group $\left(\mathrm{T}_{3-4} / \mathrm{N}_{1-3}\right)$ was significantly higher in expression of $\mathrm{CD}^{+} \mathrm{CD}^{+}$cells in peripheral blood than early group $\left(\mathrm{T}_{1-2} / \mathrm{N}_{0}\right)$. It's reported that in early tumor stages, Th1 cells are the dominant population of $\mathrm{CD}^{+} \mathrm{T}$ cells, perhaps important for immunosurveillance; while in the advanced tumor stages, FoxP3+ Treg and Th17 cells become the dominant populations. It is well recognized that tumor-infiltrating Treg cells are a major obstacle for the success of tumor immunity and immunotherapy (Curiel 2008; Perez et al. 2007; Peng et al. 2007). Huang et al. also reported that the intra-tumoral $\mathrm{CD} 4^{+} \mathrm{T}$ cells numbers were positively correlated with advanced tumor stage, large tumor size, and positive tumor metastasis, but were inversely correlated with survival of breast cancer patients (Huang et al. 2015). Therefore, this study maybe suggested that in the late tumor stage, $\mathrm{CD} 4^{+} \mathrm{T}$ cells become more important for promoting tumor growth. The expression of $\mathrm{CD}^{+} \mathrm{CD}^{+}$seemed to be decreased in early group $\left(\mathrm{T}_{1-2} / \mathrm{N}_{0}\right)$, compared to that in advanced group $\left(\mathrm{T}_{3-4} /\right.$ $\mathrm{N}_{1-3}$ ). However, except for group between $\leq 40$ age group and $\geq 60$ age group in comparison with 40-60 age group, there were no significant differences in the expression of $\mathrm{CD}_{3}^{+} \mathrm{CD}^{+}$and $\mathrm{CD}^{+}{ }^{+} \mathrm{CD} 8^{+}$in OSCC patients with different pathological patterns, genders, and locations.

Accumulating research findings suggested that there are multiple antitumor $\mathrm{T}$ cell clones in the peripheral blood of patients with lymphoma, but these $\mathrm{T}$ lymphocytes fail to retain effective antitumor properties (Yin et al. 2010, 2011). Interestingly, Yin et al. showed that imbalance T-lymphocyte subsets occurs in patients with lymphoma during different chemotherapy stages, and these T-lymphocyte subsets gradually return to normal by 3 months after chemotherapy (Yin et al. 2014). Given the poor prognosis of OSCC, the patients with OSCC $\left(\mathrm{T}_{2-4} / \mathrm{N}_{1-3}\right)$ received 2 cycles TP regime chemotherapy and radical operation, including extensive resection of the primary tumor, partial 
resection of maxillary/mandible, and functional neck dissection (Level I-V). To evaluate the dynamic effect of chemotherapy or operation on patients with OSCC, the lymphocytes subgroups were analyzed using flow cytometer. Interesting, 2 cycles TP regime chemotherapy and radical operation indeed significantly increased the expression of $\mathrm{CD}^{+} \mathrm{CD}^{+} \mathrm{T}$ cells and decreased the expression of $\mathrm{CD}^{+} \mathrm{CD}^{+} \mathrm{T}$ cells in almost all OSCC patients. The results suggested that the 2 cycles $\mathrm{CT}$ and radical operation were essential to improve the prognosis of OSCC patients. It is suggested that $\mathrm{CD} 4^{+} / \mathrm{CD} 8^{+}$ ratio is crucial to be kept in a dynamic balance, in terms of maintaining the immunological function stable (Dou et al. 2013). The ratio decreased is reported to link with a low immunological function (Erdem et al. 2012; Nugroho et al. 2012). In this study, The patients with OSCC received 2 cycles CT or radical operation had a significantly higher level of $\mathrm{CD}^{+} / \mathrm{CD}^{+}$ratio compared with that received no treatment or 1 cycle CT. NK cell is also designated as natural killer cells. NK cell could directly destroy tumor cells, and reduced level of NK cell will lead to decline of immunological function (Wang et al. 2013). Our results showed that there is no difference of expression of $\mathrm{CD}^{-} \mathrm{CD} 16^{+} \mathrm{CD} 56^{+} \mathrm{NK}$ cell in OSCC patients received different treatments, suggesting no significant influence of different treatments of NK cells on patients with OSCC. The CD19 molecule is a phenotypic marker of B cells. In EBV-associated disease, B cells are the principal targets of viral infection and play a significant role in the anti-tumor humoral responses by differentiating into antibody producing plasma B cells. The prognostic value of $\mathrm{CD} 19^{+} \mathrm{B}$ cells also has been observed in breast cancer and acute myeloid leukemia (Tredan et al. 2013; Iriyama et al. 2013). The high percentage of circulating $\mathrm{CD} 9^{+} \mathrm{B}$ cells alone correlated positively with better PFS of nasopharyngeal carcinoma (Xu et al. 2014). In our study, the expression of CD19+ B cells were only increased in OSCC patients received radical operation with different $\mathrm{T}$ stage, nodal status and pathological grading. There is no relationship between 2 cycles TP regime chemotherapy and the expression of $\mathrm{CD} 19^{+} \mathrm{B}$ cells. The mechanism need to be further explored.

\section{Conclusion}

In this study, the expression of $\mathrm{CD} 4^{+} \mathrm{T}$ cells were significantly increased in advanced tumor stage, large tumor size and positive lymph nodes metastasis, compared to that in early group. 2 cycles TP regime chemotherapy and radical therapy may be essential to increase the effects of anti-tumor immunity on patients with OSCC. However, the positive correlation between circulating $\mathrm{CD} 19^{+} \mathrm{B}$ cells and radical operation in patients with OSCC still need to be further explored in future study. The analysis of lymphocyte subgroups in peripheral blood detected by flow cytometry suggested that the lymphocyte subgroups may be the prognostic factor of OSCC.

Authors' contributions

TY, PG and ZHW participated in the design of the study, performed the statistical analysis and draft the manuscript. $\mathrm{CHL}$, JC and CX performed data collection and statistical analysis. GQZ, YCC collected samples and data. JFL, KL, YT and QY performed the statistical analysis and helped to draft the manuscript. LCW analyzed samples and collected data. All authors read and approved the final manuscript.

\section{Author details}

${ }^{1}$ Department of Head and Neck Oncology Surgery, Sichuan Cancer Hospital, No.55, Sec.4, Renminnan Road, Chengdu 610041, Sichuan, People's Republic Ofchina. ${ }^{2}$ State Key Laboratory of Oral Diseases, West China School of Stomatology, Sichuan University, Chengdu 610041, Sichuan, People's Republic Ofchina. ${ }^{3}$ Department of Clinical Laboratory, Sichuan Cancer Hospital, No.55, Sec.4, Renminnan Road, Chengdu 610041, Sichuan, People's Republic Ofchina. 


\section{Acknowledgements}

This paper was supported by the Fund of the Department of Science and Technology of Sichuan Province (Grant No. 2014JY0033) and the Sichuan Provincial Bureau of Health (Grant No. 130231).

\section{Informed consent}

Informed consent was obtained from all individual participants included in the study.

\section{Competing interests}

All procedures performed in studies involving human participants were in accordance with the ethical standards of the ethical committee of the Sichuan Cancer Hospital, China and with the 1964 Helsinki declaration and its later amendments or comparable ethical standards. So, there is no conflict of interest in this study.

\section{Received: 31 August 2015 Accepted: 29 October 2015}

Published online: 12 November 2015

\section{References}

Boucek J, Mrkvan T, Chovanec M, Kuchar M, Betka J, Boucek V et al (2010) Regulatory T cells and their prognostic value for patients with squamous cell carcinoma of the head and neck. J Cell Mol Med 14(1-2):426-433 Curiel TJ (2008) Regulatory T cells and treatment of cancer. Curr Opin Immunol 20(2):241-246 de Cos Escuin JS (2014) Diagnosis and treatment of neuroendocrine lung tumors. Arch Bronconeumol 50(9):392-396 Dou X, Wang RB, Yan HJ, Jiang SM, Meng XJ, Zhu KL et al (2013) Circulating lymphocytes as predictors of sensitivity to preoperative chemoradiotherapy in rectal cancer cases. Asian Pac J Cancer Prev 14(6):3881-3885

Dunn GP, Old LJ, Schreiber RD (2004) The immunobiology of cancer immunosurveillance and immunoediting. Immunity 21(2):137-148

Erdem MG, Cinkilic N, Vatan O, Yilmaz D, Bagdas D, Bilaloglu R (2012) Genotoxic and anti-genotoxic effects of vanillic acid against mitomycin C-induced genomic damage in human lymphocytes in vitro. Asian Pac J Cancer Prev 13(10):4993-4998

Ersvaer E, Hampson P, Wendelbo O, Lord JM, Gjertsen BT, Bruserud O (2007) Circulating T cells in patients with untreated acute myelogenous leukemia are heterogeneous and can be activated through the CD3/TCR complex. Hematology 12(3):199-207

Hsu MC, Hsiao JR, Chang KC, Wu YH, Su IJ, Jin YT et al (2010) Increase of programmed death-1-expressing intratumoral CD8 T cells predicts a poor prognosis for nasopharyngeal carcinoma. Mod Pathol 23(10):1393-1403

Huang Y, Ma C, Zhang Q, Ye J, Wang F, Zhang Y, et al (2015) CD4 ${ }^{+}$and CD8 ${ }^{+}$T cells have opposing roles in breast cancer progression and outcome. Oncotarget. Epub ahead of print

Iriyama N, Hatta Y, Takeuchi J, Ogawa Y, Ohtake S, Sakura T et al (2013) CD56 expression is an independent prognostic factor for relapse in acute myeloid leukemia with t(8;21). Leuk Res 37(9):1021-1026

Janssen EM, Lemmens EE, Wolfe T, Christen U, von Herrath MG, Schoenberger SP (2003) CD4 ${ }^{+}$T cells are required for secondary expansion and memory in CD8 ${ }^{+}$T lymphocytes. Nature 421(6925):852-856

Jozwik M, Okungbowa OE, Lipska A, Jozwik M, Smoktunowicz M, Semczuk A et al (2015) Surface antigen expression on peripheral blood monocytes in women with gynecologic malignancies. BMC Cancer 15(1):129

Kuhn S, Hyde EJ, Yang J, Rich FJ, Harper JL, Kirman JR et al (2013) Increased numbers of monocyte-derived dendritic cells during successful tumor immunotherapy with immune-activating agents. J Immunol. 191(4):1984-1992

Lau KM, Cheng SH, Lo KW, Lee SA, Woo JK, van Hasselt CA et al (2007) Increase in circulating Foxp3 ${ }^{+}$D4 ${ }^{+}$CD25(high) regulatory T cells in nasopharyngeal carcinoma patients. Br J Cancer 96(4):617-622

Liu J, Hau E, Links M, Graham PH (2014) Adenoid cystic carcinoma of the lung: response to tamoxifen after chemoradiation. Asia Pac J Clin Oncol. Epub ahead of print

Nugroho AE, Hermawan A, Nastiti K, Suven Elisa P, Hadibarata T et al (2012) Immunomodulatory effects of hexane insoluble fraction of Ficus septica Burm. F. in doxorubicin-treated rats. Asian Pac J Cancer Prev 13(11):5785-5790

Peng G, Wang HY, Peng W, Kiniwa Y, Seo KH, Wang RF (2007) Tumor-infiltrating gammadelta T cells suppress T and dendritic cell function via mechanisms controlled by a unique toll-like receptor signaling pathway. Immunity 27(2):334-348

Perez SA, Karamouzis MV, Skarlos DV, Ardavanis A, Sotiriadou NN, lliopoulou EG et al (2007) CD4+CD25+ regulatory T-cell frequency in HER-2/neu (HER)-positive and HER-negative advanced-stage breast cancer patients. Clin Cancer Res 13(9):2714-2721

Plonquet A, Haioun C, Jais JP, Debard AL, Salles G, Bene MC et al (2007) Peripheral blood natural killer cell count is associated with clinical outcome in patients with aalPI 2-3 diffuse large B-cell lymphoma. Ann Oncol 18(7):1209-1215

Sahingur SE, Yeudall WA (2015) Chemokine function in periodontal disease and oral cavity cancer. Front Immunol 6:214

Schreiber RD, Old LJ, Smyth MJ (2011) Cancer immunoediting: integrating immunity's roles in cancer suppression and promotion. Science 331(6024):1565-1570

Starska K, Głowacka E, Kulig A, Lewy-Trenda I, Bryś M, Lewkowicz P (2011a) The role of tumor cells in the modification of $T$ lymphocytes activity-the expression of the early $\mathrm{CD} 69^{+}, \mathrm{CD} 71^{+}$and the late $\mathrm{CD} 25^{+}, \mathrm{CD} 26^{+}, \mathrm{HLA} / \mathrm{DR}{ }^{+}$ activation markers on $\mathrm{TCD} 4^{+}$and $\mathrm{CD}^{+}$cells in squamous cell laryngeal carcinoma. Folia Histochem Cytobiol 49(4):579-592

Starska K, Głowacka E, Kulig A, Lewy-Trenda I, Bryś M, Lewkowicz P (2011b) Prognostic value of the immunological phenomena and relationship with clinicopathological characteristics of the tumor-the expression of the early $\mathrm{CD}_{69}{ }^{+}, \mathrm{CD}_{7} 1^{+}$and the late $\mathrm{CD} 25^{+}, \mathrm{CD}_{2} 6^{+}, \mathrm{HLA} / \mathrm{DR}^{+}$activation markers on $\mathrm{TCD} 4^{+}$and $\mathrm{CD} 8^{+}$Iymphocytes in squamous cell laryngeal carcinoma. Part II. Folia Histochem Cytobiol 49(4):593-603 
Tredan O, Manuel M, Clapisson G, Bachelot T, Chabaud S, Bardin-dit-Courageot C et al (2013) Patients with metastatic breast cancer leading to CD4 ${ }^{+} T$ cell lymphopaenia have poor outcome. Eur J Cancer 49(7):1673-1682

Wang WJ, Tao Z, Gu W, Sun LH (2013) Variation of blood T lymphocyte subgroups in patients with non- small cell lung cancer. Asian Pac J Cancer Prev 14(8):4671-4673

Xu T, Huang Z, Su B, Wang S, Wang D, Wang C et al (2014) Prognostic significance of circulating CD19+ B lymphocytes in EBV-associated nasopharyngeal carcinoma. Med Oncol 31(10):198

Yin Q, Tan H, Chen S, Yang L, Ye J, Li Y (2010) Characterization of conserved CDR3 sequence of TCR alpha- and beta-chain genes in peripheral blood T-cells from patients with diffuse large B-cell lymphoma. Hematology 15(1):48-57

Yin Q, Zha X, Yang L, Chen S, Zhou Y, Wu X et al (2011) Generation of diffuse large B cell lymphoma-associated antigenspecific Valpha6/Nbeta13+ T cells by TCR gene transfer. J Hematol Oncol. 4:2

Yin Q, Chen L, Li Q, Mi R, Li Y, Wei X et al (2014) Changes of T-lymphocyte subpopulation and differential expression pattern of the T-bet and GATA-3 genes in diffuse large B-cell lymphoma patients after chemotherapy. Cancer Cell Int. 14:85

Submit your manuscript to a SpringerOpen ${ }^{\circ}$ journal and benefit from:

- Convenient online submission

- Rigorous peer review

- Immediate publication on acceptance

- Open access: articles freely available online

- High visibility within the field

- Retaining the copyright to your article

Submit your next manuscript at $\mathbf{s p r i n g e r o p e n . c o m ~}$ 